\title{
Effects of Tear Gases on the Pulmonary System
}

\author{
Göz Yaşartan Gazların Solunum Sistemi Üstündeki Etkileri
}

\author{
Peri Meram Arbak \\ Department of Chest Diseases, Internal Medicine, Faculty of Medicine, Düzce University, Düzce, Turkey
}

\begin{abstract}
The acute effects of tear gases such as oleoresincapsicum and 2-chlorobenzylidene malononitrile are well known. Tear gases cause incapacitating inflammatory response in various tissues and organs including the lungs, eyes, nose, throat, skin and others. The final results on the pulmonary system are toxic pneumonitis, asthma aggravation, bronchitis, and rhinitis. Long term effects are irritant induced asthma and chronic obstructive pulmonary disorders. The best way to reduce the hazardous effects of these gases is not to use them at all.
\end{abstract}

KEY WORDS: Tear gases, respiratory effects, lung diseases
Oleoresincapsicum ve 2-chlorobenzylidene malononitrile gibi göz yaşartan gazların akut etkileri iyi bilinmektedir. Göz yaşartan gazlar akciğerler, gözler, burun, boğaz, cildi içeren çeşitli doku ve organlarda güçsüz bırakan yangısal yanıta yol açmaktadırlar. Solunum sistemi üstündeki son sonuçlar toksik pnömonitis, astım alevlenmesi, bronşit ve rinittir. Uzun dönemli etkileri ise irritanla indüklenen astım, kronik obstrüktif solunumsal hastalıklardır. Bu gazların zararlı etkilerini azaltmanın en iyi yolu onları hiç kullanmamaktır.

ANAHTAR SÖZCÜKLER: Göz yaşartan gazlar, solunumsal etkiler, akciğer hastalıkları

Received/Geliş Tarihi: 11.09.2013 Accepted/Kabul Tarihi: 16.09.2013

\section{INTRODUCTION}

The Turkish Police Department reported that they mostly used Oleoresincapsicum (OC) and 2-chlorobenzylidene malononitrile (CS) as tear gases for controlling protest actions [1]. OC is an organic resin derived from the pepper plant and its toxicological effect is mainly dependent on the amount of capsiacinoids in it. The capsaicinoid content determines the "hotness" of the OC product, measured in Scoville units. OC for nonlethal weapon formulas can differ in potency from 16000 Scoville Heat Units (S.H.U) to1.5 million units, with a 5-10\% solution generally recommended as an effective dose [2]. When used, OC causes incapacitating inflammatory response in various tissues and organs including the lungs, eyes, nose, throat, skin and others [3]. OC leads to wheezing, dry cough, shortness of breath, gasping, difficulty in breathing or speaking due to laryngospasm and rarely cyanosis, apnoea, and respiratory arrest in the respiratory system [4].

Chlorobenzylidenemalononitrile is a white crystalline substance that is usually mixed with the other compounds in a grenade or canister for use. The preferable form for scattering populations is intended to be a smoke or fog of suspended particles. Being an extremely severe skin and mucous membrane irritant and lacrimator, even at minute doses, CS is found to be effective for controlling crowds [5]. Respiratory symptoms due to CS are nasal irritation, rhinorrhea, coughing and shortness of breath [6]. The effects of CS usually start after 20 to 60 seconds of exposure and resolve within 30 minutes [7]. Animal studies showed that the respiratory concentration of CS 25000 to $150000 \mathrm{mg} / \mathrm{m}^{3}$ per minute would be lethal for $50 \%$ of healthy adults. When used outside, a CS grenade produces a cloud 6-9 meters in diameter, the highest CS concentration of 2000 to $5000 \mathrm{mg} / \mathrm{m}^{3}$ is detected at the centre of the cloud $[8,9]$. Those investigations led the authorities to declare the safety and effectiveness of CS as a riot control agent. However,there are some questions about the CS concentrations when used in large amounts and/or in enclosed areas.

The Turkish Medical Association published a report on the medical effects of tear gases in August 2011 [1]. At least 3 deaths were reported from Turkey; cardiac arrest following tear gas in 2007, pulmonary oedema following a great quantity of tear gas in 2011 and intracranial haemorrhage with hypertension in 2011.

Although the Turkish Police Department proposed that the usage of tear gases has been proportionally regarding dispersing the huge crowds and aggressive protesters, Amnesty International declared the inappropriate use of tear gas by police has been most devastating on the safety of demonstrators, causing an unknown number of injuries, including serious head injuries when the canisters hit protestors in Istanbul on June, 2013 [10].

Address for Correspondence / Yazışma Adresi: Peri Meram Arbak, Department of Chest Diseases, Internal Medicine, Faculty of Medicine, Düzce University, Düzce, Turkey Phone: +90 3805414108 E-mail: periarbak@hotmail.com (CTelif Hakkı 2013 Türk Toraks Derneği - Makale metnine www.toraks.dergisi.org web sayfasından ulaşılabilir.

(c) Copyright 2013 by Turkish Thoracic Society - Available online at www.toraks.dergisi.org 
The Turkish Thoracic Society has been evaluating the effects of tear gases since 2011. Intense and frequent use of tear gases even in enclosed areas led the Turkish Thoracic Society to investigate the respiratory effects. For this purpose, a group of investigators studied the long term effects of tear gases in 2012. Additionally, Turkish Thoracic Society teams from Istanbul and Ankara have just studied the acute respiratory effects of approximately 500 subjects in the June, 2013 Gezi Parkı resistance.

This report focused especially on the respiratory effects of the most frequently used tear gases; OC and CS.

\section{Experimental Studies on OC, CS, and Mechanisms of Action} Capsaicin induced a slowly developing strong atropineresistant contraction of human bronchi obtained from patients with lung cancer in vitro. Capsaicin was less potent than acetylcholine and histamine in inducing contractions of human bronchi [11]. A human bronchial epithelial cell line responded to capsaicin with increases in intracellular calcium and IL-8 cytokine release after $4 \mathrm{~h}$ exposure [12]. Capsaicinoids caused inflammation and epithelial cell death through activation of vanilloid receptors in another in vitro study performed on cultured human lung cells. Also, the authors concluded that capsaicinoids contained in pepper spray products produce airway inflammation and cause respiratory epithelial cell death [13].

The activation of the "vanilloid" receptor leads to the opening of a particular type of receptor operated cation channel. Sodium and calcium ion influx leads to depolarization, which triggers local release of neuropeptides (substance $P$, calcitonin gene-related peptide [CGRP], and neurokinin A) from sensory nerves [14-16]. Exposure of rats to OC spray $\left(150 \mathrm{mg} / \mathrm{m}^{3}\right)$ had a decreased minute volume compared to pre-exposure values, the decrease in minute volume was caused by both decreased tidal volume and decreased respiratory frequency. Histopathology evaluation revealed increased mucous secretion and interstitial oedema [17].

In an in vivo study, no fatality was observed in the rats when they were kept inside the $0.5 \mathrm{~m}^{3}$ glass cube in fives and sprayed with OC for 4, 8 and 12 second durations in which the rats were respectively exposed to OC of 24,48 and $72 \mathrm{~g}$. All the rats were observed to have intensive redness in the eyes, conjunctiva and difficulty in breathing. In the analyses of blood gases, respiratory acidosis was observed in OC exposed groups [18].

Most of the ovalbumin-sensitized guinea pigs died (7/10) after exposure to $0.11 \mathrm{mg} / \mathrm{m}^{3}$ capsaicin as a fine aerosol droplet for ten minutes. The cause of deaths was severe bronchoconstriction. When OC was sprayed into the face of the sensitized and normal guinea pigs for 1 or $4 \mathrm{~s}$, bronchoconstriction was observed, and the sensitized animals were more sensitive [19]. Several in vivo studies on mice showed $\mathrm{RD}_{50}$ (the concentration of a chemical required to produce a $50 \%$ decrease in respiratory rate for sensory irritants) levels between $0.2 \mathrm{mg} / \mathrm{m}^{3}$ to $10.4 \mathrm{mg} / \mathrm{m}^{3}[20,21]$.

Acute studies in rodents and guinea pigs using pyrotechnically-generated CS smoke indicated that short term exposure (10 to 20 minutes) to concentrations of CS of around 4 grams/metre ${ }^{3}$ or longer exposure (several hours) to levels of around 30 to $40 \mathrm{mg} / \mathrm{m}^{3}$, resulted in death. Death was due to severe lung damage (comprising haemorrhages and oedema). Animals that survived showed no pathological abnormalities when examined 14 days later [22]. In vivo studies on rats, mice, guinea-pigs, rabbits, pigeons and monkeys showed pulmonary oedema, haemorrhage and atelectasis even with the lower doses of CS $[23,24]$. When grenade CS was used via inhalation through the upper airways, respiratory depression and immediate transient increase in blood pressure occurred in anaesthetised cats. CS caused respiratory stimulation when used via tracheal cannula [25].

\section{In Summary;}

1. Capsaicinoids caused inflammation and epithelial cell death through activation of vanilloid receptors via releasing neuropeptides such as substance $P$.

2. OC exposure of rats resulted in a decrease in respiratory rate, tidal volume and led to respiratory acidosis.

3. In sensitized animal models, OC led to severe bronchoconstriction.

4. OC caused interstitial oedema in animal studies.

5. Animal studies showed that CS exposure created pulmonary oedema, haemorrhage and atelectasis even at the lower doses.

Acute and Chronic Effects of Human Exposure to OC and CS A report produced for the National Institute of Justice described a Human Effectiveness and Risk Characterization (HERC) for oleoresin capsicum (OC) hand-held devices and offered extensive knowledge. Three main mechanisms have been postulated to be responsible for the hazardous effects of $\mathrm{OC}$ in animals as well as human beings. Irritation of nonmyelinated $\mathrm{C}$ fibres by $\mathrm{OC}$ is responsible for cough and bronchoconstriction. Bronchoalveolar inflammation and cell death occur via release of neuropeptides (Substance P) in the case of exposure to OC. Finally, capsaicin may undergo bioconversion to a quinone - an activated metabolite having a multiplicity of deleterious effects such as ROS formation and consequent results such as membrane damage, enzyme inactivation, increased capillary permeability.

The effects of OC on the respiratory system of human depend on;

- The concentration of exposure,

- Duration of exposure,

- Particle size,

- Vehicle. With solutions of peripheral sensory irritations, the use of surface active substances or solvents may enhance the spread or penetration of skin and mucosae, and hence facilitate the irritant response,

Environmental conditions such as elevated temperature and increased humidity may decrease tolerance to peripheral sensory irritations and hence apparently facilitate the response,

Motivation. Increased motivation and distracting influences will, in general, increase tolerance to suprathreshold concentrations of peripheral sensory irritation [26]. According to this report; OC in fog form produces respiratory effects within 1 minute or less, and bronchoconstriction both in sensitive asthmatics and healthy individuals may occur within 1 minute or less, but the fraction of the population and the dose are not known. There may be a risk of deep pulmonary effects for fog 
and this risk will increase with foggs that have low levels of solids. Bronchoconstriction and deep pulmonary effects (such as interstitial oedema) are not expected for the stream or cone sprays whereas aspiration of liquid may be related to the stream or cone sprays [26].

Respiratory system related deaths occurred after acute exposure to OC. A case report showed that respiratory arrest occurred in a person with respiratory infection who was sprayed repeatedly [27]. Laryngospasm, laryngeal and pulmonary oedema, chemical pneumonitis and respiratory arrest occurred after intentional and accidental OC spray inhalation in children $[28,29]$.

In a custody death case, the victim was a known asthmatic, who was sprayed 10 to 15 times with pepper spray. Postmortem examination revealed severe epithelial lung damage, and the cause of death was noted as severe acute bronchospasm, probably precipitated by the use of pepper spray [4].

There are some other investigations that have not found lethal effects related to OC. In a study conducted in a clinical laboratory environment, 35 volunteers were exposed to OC or placebo spray when sitting or in a prone maximal restraint position. A slightly greater decrease in FVC and $\mathrm{FEV}_{1}$ was detected in subjects exposed OC in restraint position as compared to subjects exposed to placebo. However, the authors concluded that OC exposure did not result in abnormal spirometry, hypoxemia, or hypoventilation when compared to placebo in either the sitting or restraint position [30]. A medical record review showed that 6 out of 81 patients admitted to emergency department due to the exposure to OC had respiratory symptoms. The same study reported that approximately $10 \%$ of all subjects sprayed by police officers were admitted to hospitals, and the main causes for admittance were ocular and respiratory complaints [31].

Chronic pulmonary effects such as severe chronic bronchitis, pulmonary fibrosis and bronchiectasis were reported among chili grinders chronically exposed to capsicum, but the etiologic factor was thought to be a fungus rather than capsicum $[32,33]$. Chronic effects due to low dose exposure to OC are generally not as well known as the acute effects of OC.

Chlorobenzylidenemalononitrileis is a severe skin and mucous membrane irritant and lacrimator, even at minute doses. Symptoms related to CS are exacerbated in hot or humid weather. Some agglomerates or water repellent forms of CS (known as CS1 and CS2) can remain active for days to weeks in the environment [5]. In healthy male volunteers, a reduction in exercise ventilation volume was noted after exposure to CS aerosols under controlled conditions, but prolonged high exposure to CS in confined spaces could result in respiratory tract inflammatory changes and associated secondary infection. An infant exposed to CS in a house developed severe pneumonitis requiring therapy with steroids, oxygen, and antibiotics [34,35]. Hu et al. [5] reviewed tear gas, especially CS. The authors visited Seoul, South Korea, in July 1987. Political demonstrations that led to the use of tear gas had occurred in the preceding month. The authors interviewed and examined more than a hundred people, including individuals exposed to tear-gas, hospital staff, and bystanders. Individuals close to exploding tear gas grenades and canisters commonly sustained penetrating trauma from plastic fragments. There were reports of blister- ing skin burns from direct contact with the tear gas powder. Shopkeepers and their families in communities near where the demonstrations took place complained of cough and shortness of breath that persisted for several weeks. Hospital physicians reported that patients with asthma and chronic obstructive lung disease exposed to tear gas through open hospital windows experienced clinical deterioration in lung function.

Prolonged effects of CS were also reported in some studies. Coughing, wheezing, and dyspnoea persisted for two years after short-term exposure in a previously well 21-year old woman [36]. Among 34 young adults exposed to CS in a coach, 5 of them had respiratory symptoms, 2 had worsening of asthma, 2 had decreased exercise tolerance, and 1complained of coughing fits after exercise at the examination carried out 8 to 10 months after the exposure [37].

In a project conducted by the Turkish Thoracic Society, the long term influence of both OC and CS on the respiratory system were evaluated. Ninety three males, who were exposed to both OC and CS (mean age; $38.8 \pm 9.3$ years, total gas exposure; $8.5 \pm 6.4$, gas exposure during the last two years; $5.6 \pm 5.8$ ) were compared to 55 controls (mean age; $36.3 \pm 8.6$ years). Reported rates for resting dyspnoea during the last year $(44.1 \%)$, chest tightness $(37.6 \%)$ and exercise dyspnoea $(43.0 \%)$ were higher among subjects exposed to tear gases. Higher rates of morning cough during winter (32.3\%), morning phlegm (28.0\%), daytime cough (38.7\%), daytime phlegm (41.9\%) and phlegm for 3 months (25.8\%) were observed in subjects exposed tear gases as compared to controls. Exposure to tear gases increased the risk of chest tightness, exercise dyspnoea, morning cough during winter, phlegm approximately 1.9 to 2.4 -fold. The mean maximal mid expiratory flow rate in subjects exposed to gases $(4084.6 \pm 1235.1 \mathrm{~mL})$ was significantly lower than that of controls $(4565.9 \pm 1096.4 \mathrm{~mL})$. There was a negative correlation between MMFR and total gas exposure. Authors concluded that frequent exposure to tear gases increased respiratory symptoms and complaints by 1.9 to 2.4 -fold, while decreasing the flows in medium and small airways as a long term sequela [38].

\section{Prevention and Treatment}

Full face masks are the best choices for prevention. Breathless or hypoxic patients should be treated by supplemental oxygen. Nebulised bronchodilator therapy and steroids are beneficial when bronchoconstriction is present. In the event of airway or ventilatory compromise, appropriate intervention must be carried out immediately [39].

\section{Conflict of Interest}

No conflict of interest was declared by the author.

Peer-review: Invited.

\section{Acknowledgements}

The author thanks to Özlem Özdemir Kumbasar for her contributions during the preperation of this manuscript.

\section{Çıkar Çatışması}

Yazar herhangi bir çıkar çatışması bildirmemiştir.

Hakem değerlendirmesi: Davetli. 


\section{Teşekkür}

Yazar, Sayın Özlem Özdemir Kumbasar'a yazının hazırlık sürecindeki katkılarından dolayı teşekkür eder.

\section{REFERENCES}

1. Türk Tabipleri Birliği. Kimyasal Silahlar Gösteri Kontrol Ajanları. Birinci Baskı, Ağustos 2011, Ankara Türk Tabipleri Birliği Yayınları 2011.

2. Rumsfield JA, West D. Topical Capsaicin in Dermatological and Peripheral Pain Disorders. DICP Ann. Pharmacotherap 1991;25:381-7.

3. Melecitathe MA. Oleoresin Capsicum Toxicology Evaluation and Hazard Review. SANDIA REPORT. Unlimited Release Printed October 1995. SAND95-2129 UC-607.

4. Steffee $\mathrm{CH}$, Lantz PE, Flannagan LM, et al. Oleoresin capsicum (pepper) spray and "in custody deaths". Am J Forensic Med Path 1995;16:185-92. [CrossRef]

5. Hu H, Fine J, Epstein P, et al. Tear Gas- Harrassing Agent or Toxic Chemical Weapon? JAMA 1989;262:660-3. [CrossRef]

6. Smith J, Greaves I. The Use of Chemical Incapacitant Sprays: A Review. J Trauma 2002;52:595-600. [CrossRef]

7. Fraunfelder FT. Is CS gas dangerous? BMJ 2000;320:458-9. [CrossRef]

8. Sanford JP. Medical aspects of riot control (harrasing) agents. Annu Rev Med 1976;27:412-29. [CrossRef]

9. Wiegand DA. Cutaneous reactions to the riot control agent CS. Milit Med 1969;134:437-40.

10. http://www.amnesty.org/en/news/turkey-disgraceful-useexcessive-police-force-istanbul 2013-06-01.

11. Lundberg JM, Martling CR, Saria A. Substance P and capsaicininduced contraction of human bronchi. Acta Physiol Scand 1983;119:49-53. [CrossRef]

12. Veronesi B, Carter JD, Devlin RB, et al. Neuropeptides and capsaicin stimulate the release of inflammatory cytokines in a human bronchial epithelial cell line. Neuropeptides 1999;33:447-56. [CrossRef]

13. Reilly CA, Taylor JL, Lanza DL, et al. Capsaicinoids cause inflammation and epithelial cell death through activation of vanilloid receptors. Toxicol Sci 2003;73:170-81. [CrossRef]

14. Lundblad L, Lundberg JM. Capsaicin sensitive sensory neurons mediate the response to nasal irritation induced by the vapor phase of cigarette smoke. Toxicology 1984;33:1-7. [CrossRef]

15. Martling CR. Sensory nerves containing tachykinins and CGRP in the lower Airways. ACTA Physiologica Scandinavica 1987;130:1-57.

16. Stjarne P. Sensory and motor reflex control of nasal mucosal blood flow and secretion: clinical implications in non-allergic nasal hyperreactivity. ACTA Physiologica Scandinavica 1991;142:1-64.

17. Debarre S, Karinthi L, Delamanche S, et al. Comparative acute toxicity of o-chlorobenzylidene malononitrile (CS) and oleoresin capsicum (OC) in awake rats. Hum Exp Toxicol 1999;18:724-30. [CrossRef]

18. Seyhan E, Mert N, Mert H. The Effect of Pepper Gas (OC) on Some Biochemical Parameters in Rats. Kafkas Univ Vet Fak Derg 2012;18:259-66.

19. Busker RW, van de Meent D, Bergers WWA. Safety evaluation of pepper spray in the ovalbunim sensitized guinea pig. In Fraunhofer-Institut fuer Chemsiche Technologie (Ed.), 1st Euro- pean Symposium on Non-Lethal Weapons. Ettlingen, Germany: European Working Group Non-Lethal Weapons 2001.pp.8-12.

20. Alarie Y, Keller LW. Sensory irritation by Capsaicin. Environmental Physiology \& Biochemistry 1973;3;169-81.

21. Morris JB, Symanowicz PT, Olsen JE, et al. Immediate sensory nerve-mediated respiratory responses to irritants in healthy and allergic airway-diseased mice. J Appl Physiol 2003;94:1563-71.

22. Ballantyne B, Callaway S. Inhalation toxicology and pathology of animals exposed to o-chlorobenzylidene malononitrile (CS). Med Sci Law 1972;12:43-65.

23. Punte $\mathrm{Cl}$, Weimer JT, Ballard TA, Wilding JL. Toxicologic studies on o-chlorobenzylidene malononitrile. Toxicol Appl Pharmacol 1962;4:656-62. [CrossRef]

24. Striker GE, Streett CS, Ford DF, et al. Edgewood Arsenal Technical Rep 1967:4071.

25. Brimblecombe RW, Green DM, Muir AW. Pharmacology of 0-chlorobenzylidene malononitrile (CS). Br J Pharmacol 1972;44:561-76. [CrossRef]

26. Haber L, Nance P, Maier A, et al. Human Effectiveness And Risk Characterization Of Oleoresin Capsicum (OC) And Pelargonic Acid Vanillylamide (PAVA Or Nonivamide) Hand-Held Devices. AFRL-RH-BR-TR-2008-0002, 1-254.

27. Smith G, Stopford W. Health Hazards of Pepper Spray. NCMJ 1999:60:268-74.

28. Winograd HL. Acute Croup in an Older Child. Clin Ped 1977; 16:884-7. [CrossRef]

29. Billmire D, Vinocur C, Ginda M. Pepper spray induced respiratory failure treated with extracorporeal membrane oxygenation. Pediatrics 1996;98:961-3.

30. Chan TC, Vilke GM, Clausen J, et al. The effect of oleoresin capsicum "pepper" spray inhalation on respiratory function. J Forensic Sci 2002;47:299-304.

31. Watson WA, Stremel KR, Westdorp EJ. Oleoresin capsicum (Cap-Stun) toxicity from aerosol exposure. Ann Pharmacother 1996;30:733-5.

32. Urogoda CG. Symptoms among chilli grinders. Br J Indus Med $1967 ; 24: 162-4$

33. Lankatilake $\mathrm{KN}$, Urogoda CG. Respiratory function in chilli grinders. Occup Med 1993;43:139-42. [CrossRef]

34. Cotes JE, Evans LR, Johnson GR, et al. The effect of CS aerosol upon exercise ventilation and cardiac frequency in healthy men. J Physiol 1972;222:77-8.

35. Park S, Giammona ST. Toxic effects of tear gas on an infant following prolonged exposure. AJDC 1972;123:245-6.

36. Hu H, Christiani D. Reactive airways dysfunction after exposure to teargas [letter]. Lancet 1992;339:1535. [CrossRef]

37. Karagama YG, Newton JR, Newbegin CJR. Short-term and long-term physical effects of exposure to CS spray. J R Soc Med 2003;96:172-4. [CrossRef]

38. Arbak PA, Başer I, Kumbasar OO, et al. The Long Term Influence Of Tear Gases On Human's Respiratory System. Turkish Thoracic Society 16. Annual Congress. Issue 2, Supplement 1, April 2013; 54.

39. Oh JJ, Yong R, Ponampalam R, et al. Mass casualty incident involving pepper spray exposure: impact on the emergency department and management of casualties. Hong Kong J Emerg Med 2010;17:352-9. 
Reproduced with permission of the copyright owner. Further reproduction prohibited without permission. 